\title{
Attitudes and opinions of counselors about education of gifted students
}

\author{
Nisa Gökden Kaya ${ }^{1}$, Hasan Said Tortop ${ }^{2}$ \\ ${ }^{1}$ Department of Child Development, Hitit University, Turkey \\ ${ }^{2}$ Department of Child Development, Istanbul Esenyurt University, Turkey
}

\section{Article Info \\ Article history: \\ Received Mar 5, 2020 \\ Revised Sep 21, 2020 \\ Accepted Oct 12, 2020}

\section{Keywords:}

Attitude

Counseling

Diagnosing gifted

Gifted education

Gifted student

\begin{abstract}
Counselors play effective roles not only in diagnosing but also in education of gifted students who lead the development of the societies. This study aimed to examine the attitudes and opinions of the counselors about the education of the gifted students. In the study, descriptive survey model is used. Both qualitative and quantitative data was collected within mixed method, according to the principles of pragmatist philosophy. "Attitude Scale towards Gifted Education" was applied to 250 counselors in order to collect quantitative data. The scale, which consists of 14 items, was developed by Gagné and Nadeau and adapted to Turkish by Tortop. The qualitative data was collected by semi-structured interview form consists of four questions about opinions on education of gifted students in Turkey, and was applied to 40 counselors. The mean of scores gathered from "Attitude Scale towards Gifted Education" was found 3.6 which is evaluated as slightly positive attitude. The scores were analyzed according to gender, seniority, having gifted students and institution of counselors, by using t test and ANOVA. Content analysis was performed for qualitative data that was gathered from interviews. The majority of counselors have stated that there are problems in education and diagnosis of gifted students.
\end{abstract}

This is an open access article under the CC BY-SA license.

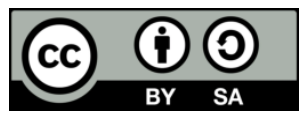

\section{Corresponding Author:}

Nisa Gökden Kaya,

Department of Child Development,

Hitit University,

Çorum, Turkey.

Email: nisakay@gmail.com

\section{INTRODUCTION}

Gifted individuals remind of jewels that need to be processed, because they constitute $2 \%$ in the society and need special education in order to reach their potential. Gifted students are characterized by fast cognitive development compared to their peers. They differ from their peers in terms of learning speed, depth of learning and knowledge they possess [1]. Gifted students need to be diagnosed correctly and educated according to their needs, in order to be able to give original works in the field of science and art. The fact that gifted students need special education is not always accepted due to prejudices such as, "Gifted are already superior, and there is no need for extra education. They can improve themselves in any environment. Additional education creates an elite class; this creates problems that society cannot overcome. The institutions that chose students are for gifted. Special education should not be concerned with gifted children." Because of these prejudices, negative attitudes can be seen towards education of gifted students [2]. The most important factor underlying teachers' attitudes towards students with special education needs is to be knowledgeable about the subject. Teachers have negative attitudes if they do not have enough 
knowledge about the group they teach. In a study conducted on experienced and inexperienced group of teachers show that the inexperienced group of teachers has higher negative judgments about gifted children than the experienced group [3]. Furthermore, teachers who were trained about gifted education both showed greater teaching skills and also created more positive class climates compared to the teachers who did not have training about gifted education [4]. However, according to research in Turkey teachers do not have sufficient knowledge and need in-service training in this context $[5,6]$.

The achievement of programs for gifted students is based on attitudes towards the education of gifted students; thus, when developing a program for gifted students, the first question should be "what is our attitude towards the education of gifted students?" [1]. Despite this fact, in Turkey, there are limited numbers of research that explores attitudes of teachers towards the education of gifted [5-8]. The results of these studies reveal that the attitudes of teachers towards gifted education range from unstable level to slightly positive level. A study with 323 teachers from 14 different branches, determined that the teachers' attitudes about the gifted education were slightly positive whereas Psychological Counseling and Guidance teachers have the highest average score of attitudes towards gifted education [8]. School counselors help gifted students with concerns regarding various aspects of their gifted experience. A study that determined which counseling concerns are experienced by gifted students with 153 participants. Findings show that school counselors have important roles in the academic, career and personal/social domains of gifted students [9]. Furthermore, counselors provide information and perspective regarding acceleration to their parents and educators [10]. In this context, school counselors are experts whose attitudes are crucial in education of gifted. A survey study determined opinions and training needs of the guidance teachers for gifted students with a study group consisted of 95 guide teachers working in secondary and high schools in North Cyprus. The average score of the opinions of the guidance teachers towards the gifted students was within the limits of "undecided", which revealed negative connotations about gifted students [11]. A qualitative research with 22 school psychological counselors, examined the opinions of school counselors on giftedness, the education of gifted students and the services for gifted students at schools. According to the findings, school counselors emphasized that although gifted children are very precious; their value is not sufficiently recognized and evaluated. Another finding of the study revealed that counselors stated that because of lack of an education curriculum, the families and teachers expose positive discrimination to these students; while their peers expose negative discrimination and exclude them [12].

Gifted students have unique needs due to asynchronous development. In that sense psychological counselors help them not only to improve their skills and achieve self-realization [13], but also solve their emotional and social problems. Research results reveal that school counselors who are aware of and knowledgeable about the unique needs and development of gifted students, report more frequent involvement, including advocacy with these students [14]. In addition, counselors provide information and counseling services not only to students, but also to parents and educators in order to serve collaboratively. Gifted students require special counseling by well-educated professionals [15]. The role of counselors cannot be denied in the diagnosing and education of gifted students [16]. In this context, the attitudes and opinions of counselors towards education of gifted are important and should to be investigated. This study depends on self-report data; it is assumed that the counselors are sincere in applying the measurement tools. Despite this limitation, considering the scarcity of studies conducted in Turkey on this issue, it is thought that the results of this research will direct the future research and applications. This research aims to examine the attitudes and opinions of the counselors regarding the education of the gifted students. The problem of the research is "What are the attitudes and opinions of the counselors about the education of the gifted students?"

\section{RESEARCH METHOD}

In this research, descriptive survey model was applied. The data was gathered by both qualitative and quantitative methods, which is called mixed method. The research using mixed method is stronger than the research using only one method, more responsive to the research questions and more adequate to prevent data abduction [17]. Mixed method is preferred in order to provide a multidimensional and holistic view. Therefore, the limitations of 'prejudice' in the quantitative method and 'inability to understand the context' in qualitative method is balanced. In this study, parallel mixed method was selected from the mixed method types. In the parallel mixed method, both quantitative and qualitative data are collected simultaneously. All collected data is combined. The results are used to understand the research problem [18]. In the research process, quantitative and qualitative data were taken together, analyzed separately and the results of the analysis were interpreted separately and then together.

The study was carried out in the first term of 2018-2019 academic year, with 250 counselors volunteering to participate in the research, working in various cities in Turkey. Snowball (chain) sampling and maximum diversity techniques were used from purposive sampling method. In the purposive sampling, 
the judgment of the researcher is used about the selection of the study group that is most suitable for the purpose of the research [17]. Distribution of counselors' demographic features is shown on Table 1.

Table 1. Demographic features of the counselors participating in the study

\begin{tabular}{clcc}
\hline Variable & \multicolumn{1}{c}{ Demographic feature } & $\mathrm{n}$ & $\%$ \\
\hline \multirow{2}{*}{ Gender } & Female & 187 & 74.8 \\
& Male & 63 & 25.2 \\
& 0-10 years & 64 & 25.6 \\
& 11-19 years & 93 & 37.2 \\
& 20 years and over & 93 & 37.2 \\
\multirow{5}{*}{ Working with gifted students } & Yes & 129 & 51.6 \\
& No & 121 & 48.4 \\
& Primary school & 64 & 25.6 \\
& Secondary school & 54 & 21.6 \\
& High school & 105 & 42 \\
& Guidance and Research Center & 20 & 8 \\
& Science and Art Center & 7 & 2.8 \\
\hline
\end{tabular}

As shown in Table 1,74.8\% of participants are female and $25.2 \%$ are male. The proportion of those who have 0-10 years seniority is $25.6 \%$; while the proportion of those who have 11-19 years of seniority is $37.2 \%$, it is $37.2 \%$ who have over 20 years and over. $51.6 \%$ of the participants had gifted students, while $48.4 \%$ did not have gifted students. $25.6 \%$ of participants work in primary school, $21.6 \%$ in secondary school, $42 \%$ in high school, $8 \%$ in Guidance and Research Center and 2.8\% in Science and Art Center. In this research, personal information form for the demographic features, "Attitude Scale towards Gifted Education" and interview form related to the education of gifted students in Turkey were used. The quantitative data were collected using the scale "Attitude Scale towards Gifted Education" developed by Gagné and Nadeau [19]. The original of the scale consists of 34 items and 6 sub-dimensions. The scale was adapted to Turkish, revised and shortened by Tortop [20]. The scale is five-point Likert -type and consists of 14 items, 7 of which are positive and 7 of which are negative. There are three sub-dimensions of the scale which are: 'Need and Support Dimension', 'Resistance to Objections Dimension' and 'Ability Grouping Dimension.' Getting an average of 2.00 points and below is evaluated as negative attitude, between 2.00 to 2.74 points means very low negative attitude, between 2.75 and 3.25 points reflect ambivalent attitude, between 3.26 to 4.00 points means slightly positive attitude, 4.00 points and above is considered as positive attitude. A reliability analysis was performed to determine the reliability level of the scale used in the study and the Cronbach's alpha coefficient was obtained. Accordingly, the Cronbach's alpha coefficient for 'Needs and Support for Talent' is 0.710; for 'Responding to special services to high talents' is 0.660; for 'Special Ability Class Creation Dimension' is 0.796 . For the total scale, it is 0.828 . The results show that the scale is a reliable measurement tool.

Qualitative data was collected from 40 counselors from the study group, by a semi-structured interview form consisting of 4 questions about the education of gifted in Turkey, prepared by the researchers. While preparing the interview form, first of all, the literature review was done in accordance with the purpose of the study and then opinions are received from three academicians who are the field experts. Quantitative data were analyzed with SPSS 20.0 program. In order to test whether the total scores of teachers are distributed normally, Shapiro-Wilk Test was used. The result of Shapiro-Wilk Test was .072 (p > 0.05) which shows that scores are distributed normally, thus parametric tests were used. The t-test and one-way ANOVA test were used in independent groups to determine the means and the significance of the difference between the means of attitude scale scores and sub-dimensions, in terms identified variables. Content analysis was conducted to analyze the qualitative data obtained from the interviews. In the content analysis, similar data are organized by bringing together within certain concepts and themes and data is interpreted [21]. Qualitative data were analyzed using frequency distributions and percentage. To ensure validity and reliability, two experts also analyzed separately from the researchers. According to the reliability formula, over $70 \%$ of the consensus is reliable [22].

\section{RESULTS AND DISCUSION}

\subsection{Results}

Firstly, the quantitative data gathered from "Attitude Scale towards Gifted Education" are analyzed. The mean of scores of Need and Support subscale is 4.02 and standard deviation (S. d.) is 0.60; the mean of Resistance to Objections subscale is 3.42 and S. d. is 0.65 ; the mean of Ability Grouping scores is 3.36 and S. d. is 0.65 . The mean of the score of total scale is 3.6 and S. d. is 0.47 . Given that the highest possible score is 
5, it can be said that the counselors' attitudes are slightly positive. Then, the scores are analyzed according to variables such as gender, seniority, having gifted students and institution of counselors. The scores are analyzed according to gender. The results of t-test are shown in Table 2.

Table 2. T-test results of counselors' attitudes according to gender variable

\begin{tabular}{|c|c|c|c|c|c|c|}
\hline Dimension & Gender & $\mathrm{n}$ & Mean & S.d. & $\mathrm{t}$ & $\mathrm{P}$ \\
\hline \multirow{2}{*}{ Need and Support } & Female & 187 & 4.02 & 0.59 & \multirow{2}{*}{0.15} & \multirow{2}{*}{0.87} \\
\hline & Male & 63 & 4.01 & 0.62 & & \\
\hline \multirow{2}{*}{ Resistance to Objections } & Female & 187 & 3.39 & 0.65 & \multirow{2}{*}{-1.07} & \multirow{2}{*}{0.28} \\
\hline & Male & 63 & 3.49 & 0.67 & & \\
\hline \multirow{2}{*}{ Ability Grouping } & Female & 187 & 3.31 & 0.65 & \multirow{2}{*}{-2.11} & \multirow{2}{*}{$0.03^{*}$} \\
\hline & Male & 63 & 3.51 & 0.71 & & \\
\hline \multirow{2}{*}{ Attitude towards Gifted Education (Total) } & Female & 187 & 3.57 & 0.46 & \multirow{2}{*}{-1.40} & \multirow{2}{*}{0.16} \\
\hline & Male & 63 & 3.67 & 0.49 & & \\
\hline
\end{tabular}

As shown in Table 2, there is no significant differences between the scores $(p>0.05)$ of the subscales of need and support, resistance to objections and total score of the scale. There is a significant difference between the scores of the ability grouping dimension $(p<0.05)$. The male counselors' scores are significantly higher than the female counselors' scores. In order to determine whether there is a meaningful difference between the means of scores in terms of seniority, one-way ANOVA test was applied. The results are presented in Table 3.

\begin{tabular}{clccccc} 
Table 3. ANOVA results of counselors' attitudes according to seniority variable \\
\hline Dimension & \multicolumn{1}{c}{ Seniority } & n & Mean & S. d. & t & p \\
\hline \multirow{2}{*}{ Need and Support } & $0-10$ years & 64 & 3.96 & 0.55 & & \\
& $11-19$ years & 93 & 4.10 & 0.63 & 1.19 & 0.30 \\
& 20 years and over & 93 & 3.99 & 0.60 & & \\
Resistance to Objections & $0-10$ years & 64 & 3.30 & 0.63 & & \\
& $11-19$ years & 93 & 3.50 & 0.65 & 1.66 & 0.19 \\
& 20 years and over & 93 & 3.41 & 0.66 & & \\
Ability Grouping & $0-10$ years & 64 & 3.23 & 0.64 & & \\
& $11-19$ years & 93 & 3.48 & 0.65 & 3.22 & $0.04^{*}$ \\
& 20 years and over & 93 & 3.32 & 0.64 & & \\
Attitude towards Gifted Education (Total) & $0-10$ years & 64 & 3.49 & 0.40 & & \\
& $11-19$ years & 93 & 3.69 & 0.49 & 3.56 & $0.03^{*}$ \\
& 20 years and over & 93 & 3.57 & 0.47 & & \\
\hline
\end{tabular}

$$
* \mathrm{p}<0.05
$$

The results of one-way ANOVA show that there is no significant difference between the scores of need and support and resistance to objections dimensions ( $p>0.05$ ). A significant difference is found between the scores of abilities grouping dimension and the total scores of the scale $(\mathrm{p}<0.05)$. According to the LSD test; the mean scores of counselors with 11-19 years seniority is significantly greater than the mean scores of counselors with $0-10$ year's seniority. Table 4 shows t-test results of scores in terms of having gifted students.

Table 4. T-test results of counselors' attitudes according to having gifted student's variable

\begin{tabular}{|c|c|c|c|c|c|c|}
\hline Dimension & Having gifted students & $\mathrm{n}$ & Mean & S. d. & $\mathrm{t}$ & $\mathrm{p}$ \\
\hline \multirow{2}{*}{ Need and Support } & Yes & 129 & 3.95 & 0.58 & \multirow{2}{*}{-2.00} & \multirow{2}{*}{$0.04 *$} \\
\hline & No & 121 & 4.10 & 0.61 & & \\
\hline \multirow{2}{*}{ Resistance to Objections } & Yes & 129 & 3.41 & 0.65 & \multirow{2}{*}{-0.09} & \multirow{2}{*}{0.92} \\
\hline & No & 121 & 3.42 & 0.66 & & \\
\hline \multirow{2}{*}{ Ability Grouping } & Yes & 129 & 3.27 & 0.62 & \multirow{2}{*}{-2.22} & \multirow{2}{*}{$0.02 *$} \\
\hline & No & 121 & 3.45 & 0.68 & & \\
\hline \multirow{2}{*}{ Attitude towards Gifted Education (Total) } & Yes & 129 & 3.54 & 0.43 & \multirow{2}{*}{-1.92} & \multirow{2}{*}{0.06} \\
\hline & No & 121 & 3.66 & 0.50 & & \\
\hline
\end{tabular}


Table 4 shows that mean scores of counselors who do not have gifted students are significantly higher than the mean scores of counselors who have gifted students, in Need and Support Dimension and Ability Grouping Dimension $(\mathrm{p}<0.05)$. There is no significant difference between the mean scores of Resistances to Objections dimension and the total scale scores ( $p>0.05$ ). The results of One-Way ANOVA, to determine the difference between the means of scores in terms of institution, are given in Table 5 .

Table 5. ANOVA results of counselors' attitudes according to institution variable

\begin{tabular}{|c|c|c|c|c|c|c|}
\hline Dimension & Institution & $\mathrm{n}$ & Mean & S. d. & $\mathrm{t}$ & $\mathrm{p}$ \\
\hline \multirow{5}{*}{ Need and Support } & Primary school & 64 & 3.83 & 0.67 & & \\
\hline & Secondary school & 54 & 3.94 & 0.54 & & \\
\hline & High school & 105 & 4.14 & 0.59 & 3.67 & $0.00^{*}$ \\
\hline & Guidance and Research Center & 20 & 4.25 & 0.43 & & \\
\hline & Science and Art Center & 7 & 4.04 & 0.39 & & \\
\hline \multirow{5}{*}{ Resistance to Objections } & Primary school & 64 & 3.42 & 0.63 & & \\
\hline & Secondary school & 54 & 3.39 & 0.51 & & \\
\hline & High school & 105 & 3.41 & 0.70 & 0.11 & 0.97 \\
\hline & Guidance and Research Center & 20 & 3.43 & 0.83 & & \\
\hline & Science and Art Center & 7 & 3.57 & 0.78 & & \\
\hline \multirow{5}{*}{ Ability Grouping } & Primary school & 64 & 3.35 & 0.55 & & \\
\hline & Secondary school & 54 & 3.21 & 0.51 & & \\
\hline & High school & 105 & 3.45 & 0.74 & 1.18 & 0.32 \\
\hline & Guidance and Research Center & 20 & 3.33 & 0.76 & & \\
\hline & Science and Art Center & 7 & 3.35 & 0.69 & & \\
\hline \multirow{5}{*}{ Attitude towards Gifted Education (Total) } & Primary school & 64 & 3.53 & 0.44 & & \\
\hline & Secondary school & 54 & 3.51 & 0.36 & & \\
\hline & High school & 105 & 3.66 & 0.51 & 1.43 & 0.22 \\
\hline & Guidance and Research Center & 20 & 3.67 & 0.52 & & \\
\hline & Science and Art Center & 7 & 3.65 & 0.52 & & \\
\hline
\end{tabular}

Table 5 indicates that there is significant difference between Need and Support Dimension according to institution variable $(\mathrm{p}<0.05)$. According to the LSD test; the mean scores of counselors working in high schools and Guidance and Research Centers are significantly higher than the counselors working in primary schools $(\mathrm{p}>0.05)$. There is no significant difference between Resistance to Objections, Ability Grouping Dimensions and the total scores in terms of institution ( $p>0.05)$. Content analysis is performed to analyze the qualitative data. Similar content codes are put within themes and categories. The data analyzed by using frequency distributions (f) and percentages (\%) are given in Table 6 to Table 8.

Table 6. Counselors' opinions about practices on diagnostics and education of gifted in Turkey

\begin{tabular}{|c|c|c|c|c|}
\hline Themes & Categories & Content codes & $\mathrm{f}$ & $\%$ \\
\hline \multirow[t]{2}{*}{$\begin{array}{l}\text { Opinions on } \\
\text { insufficiency of } \\
\text { practices }\end{array}$} & $\begin{array}{l}\text { Opinions on the } \\
\text { inadequacy of } \\
\text { the practices } \\
\text { due to the } \\
\text { conditions }\end{array}$ & $\begin{array}{l}\text { No institution for gifted, except for Science and Art Center. } \\
\text { Lack of quality of Science and Art Center due to fast } \\
\text { widespread. } \\
\text { Classroom teachers and parents are lack of knowledge about } \\
\text { the subject. } \\
\text { Conditions are not same everywhere in Turkey. } \\
\text { No standardized system. } \\
\text { There are not enough experts for diagnostics. }\end{array}$ & 17 & 42.5 \\
\hline & $\begin{array}{l}\text { Opinions on the } \\
\text { inadequacy of } \\
\text { the practices } \\
\text { due to the } \\
\text { quality of exam }\end{array}$ & $\begin{array}{l}\text { IQ is not enough for diagnostics; mechanical intelligence is not } \\
\text { evaluated. } \\
\text { Diagnostics should be done by observations and in earlier ages. } \\
\text { Frequent change of exam rules. } \\
\text { The reliability of the test is low, tests are not culturally adapted } \\
\text { and are inadequate. }\end{array}$ & 18 & 45 \\
\hline $\begin{array}{l}\text { Positive opinions } \\
\text { about practices }\end{array}$ & $\begin{array}{l}\text { Opinions about } \\
\text { the studies are } \\
\text { sufficient }\end{array}$ & $\begin{array}{l}\text { Practices are enough. } \\
\text { Gifted education gained importance. } \\
\text { Widespread of Science and Art Centers. }\end{array}$ & 3 & 7.5 \\
\hline $\begin{array}{l}\text { Having no knowledge } \\
\text { about practices }\end{array}$ & $\begin{array}{l}\text { Having no } \\
\text { knowledge }\end{array}$ & $\begin{array}{l}\text { I do not have enough knowledge. } \\
\text { I have no knowledge. }\end{array}$ & 2 & 5 \\
\hline & & Total & 40 & 100 \\
\hline
\end{tabular}

As seen in Table 6, $42.5 \%$ of the counselors have opinion on the inadequacy of the practices due to the conditions. Also $45 \%$ of the counselors reported opinions on the inadequacy of the practices due to the quality of exam. While the percentage of counselors who reported positive opinions about the studies were 
$7.5 \%$ and $5 \%$ of the counselors stated that they did not have any knowledge about the subject. For example, Counselor 7 stated, "There is no institution for gifted, except for Science and Art Center." Counselor 12 responded "In my opinion, diagnostics should be done in earlier ages, in preschool period."

Table 7 shows that $65 \%$ of counselors have opinions that roles related to giving information to classroom teachers, $20 \%$ of the counselors stated that roles related to giving information to parents and $15 \%$ of the counselors have opinions on need of knowledge in their role. For example, Counselor 3 answered as "Counselors should work cooperatively with classroom teachers." Counselor 21 stated that "Counselors lack of training about diagnosis of gifted. They should be trained."

Counselors' suggestions about the education of gifted in Turkey are given in Table 8 . As seen in the table, $25 \%$ of the counselors suggest that the intelligent test be more reliable and culturally adapted. $12.5 \%$ of the counselors have suggestions about the diagnosis procedure. Most of the counselors (62.5\%) have suggestions about the institutions for gifted. For example, Counselor 5 answered as "Diagnosing should not depend on intelligence only. Other components of giftedness should be evaluated." Counselor 40 responded, "Ministry of National Education should open separate and free schools with special curriculum for the genius students."

Table 7. Counselors' opinions about counselors' role in diagnosis of gifted in Turkey

\begin{tabular}{|c|c|c|c|c|}
\hline Themes & Categories & Content codes & $\mathrm{f}$ & $\%$ \\
\hline \multirow[t]{2}{*}{$\begin{array}{c}\text { Opinions on } \\
\text { sufficiency of } \\
\text { counselors in their role }\end{array}$} & $\begin{array}{l}\text { Roles related to giving } \\
\text { information to } \\
\text { classroom teachers }\end{array}$ & $\begin{array}{l}\text { The role of the counselor is important, counselors are } \\
\text { experts in diagnosis of gifted so they give information to } \\
\text { classroom teachers } \\
\text { The counselors should cooperate with classroom teachers } \\
\text { in diagnosis of gifted } \\
\text { Classroom teachers are more active in diagnosis of gifted, } \\
\text { counselors should give information to classroom teachers } \\
\text { Counselors share their observations about students with } \\
\text { classroom teachers }\end{array}$ & 26 & 65 \\
\hline & $\begin{array}{l}\text { Roles related to giving } \\
\text { information to parents }\end{array}$ & $\begin{array}{l}\text { Parents are senseless, counselors should guide them. } \\
\text { Parents need to be informed by counselors }\end{array}$ & 8 & 20 \\
\hline $\begin{array}{l}\text { Opinions on } \\
\text { insufficiency of } \\
\text { counselors in their role }\end{array}$ & $\begin{array}{l}\text { Opinions on need of } \\
\text { knowledge in their role }\end{array}$ & $\begin{array}{l}\text { In order to achieve the role, counselors should be } \\
\text { knowledgeable about gifted. } \\
\text { Counselors should be trained about diagnosis of gifted. }\end{array}$ & 6 & 15 \\
\hline & & Total & 40 & 100 \\
\hline
\end{tabular}

Table 8. Counselors' suggestions about the education of gifted in Turkey

\begin{tabular}{|c|c|c|c|c|}
\hline Themes & Categories & Content codes & $\mathrm{f}$ & $\%$ \\
\hline \multirow{2}{*}{$\begin{array}{l}\text { Suggestions about } \\
\text { diagnostics of gifted }\end{array}$} & $\begin{array}{l}\text { Suggestions about } \\
\text { test used }\end{array}$ & $\begin{array}{l}\text { The intelligent test should be more reliable. } \\
\text { The intelligent test should be culturally adapted. }\end{array}$ & 10 & 25 \\
\hline & $\begin{array}{l}\text { Suggestions about } \\
\text { procedure }\end{array}$ & $\begin{array}{l}\text { Should be done in earlier ages. } \\
\text { Should be multidirectional. }\end{array}$ & 5 & 12.5 \\
\hline \multirow[t]{2}{*}{$\begin{array}{l}\text { Suggestions about } \\
\text { institutions for gifted }\end{array}$} & $\begin{array}{l}\text { Suggestions about } \\
\text { institutions }\end{array}$ & $\begin{array}{l}\text { There should be separate schools for genius students. } \\
\text { The quality and quantity of Science and Art Centers should be increased. }\end{array}$ & 25 & 62.5 \\
\hline & & Total & 40 & 100 \\
\hline
\end{tabular}

\subsection{Discussion}

Despite the myth or misconception regarding gifted students can success automatically [23], gifted students face some problems in education. Counselors have significant roles in helping the gifted students to overcome personal crises [24]. Counselors need to be aware of the unique challenges of gifted students [25]. Social difficulties, perfectionism, academic anxiety, and asynchronous development are examples to challenges of gifted students [26-28]. In that sense, the attitudes and opinions of counselors, who have important roles in gifted education, is needed to be examined [29].

In this study, the average of the total scores of the counselors' attitude towards gifted education was found to be 3.6 which is evaluated as slightly positive attitude. This finding is similar to the results of the previous research [8]. This research also evaluated whether the attitudes of counselors differed according to gender, seniority, having gifted students and institution variables. According to gender, there were no significant differences between the scores for the subscales of need and support, resistance to objections dimensions and the total score of the scale. The only significant difference was between the scores of the ability grouping dimension. The male counselors' scores are significantly higher than the female counselors' scores. In the literature, there are research results indicating that the attitudes of teachers towards gifted education do not differ in terms of gender [5,8]. There was no significant difference between the scores of 
need and support and resistance to objections dimensions while there is a significant difference between the scores of abilities grouping dimension and the total scores of the scale according to the seniority. The scores of counselors with 11-19 years seniority were significantly greater than the mean scores of counselors with 010 year's seniority group. This result may be explained by experience of counselors. The mean scores of Need and Support and Ability Grouping Dimensions of counselors who do not have gifted students were significantly higher than the scores of counselors who have gifted students. However, there were no significant difference between the mean scores of Resistances to Objections dimension and the total scale scores.

According to Need and Support dimension, the mean scores of counselors working in high schools and Guidance and Research Centers are significantly higher than the counselors working in primary schools. There is no significant difference between Resistance to Objections, Ability Grouping Dimensions and the total scores in terms of institution. An extensive study of 35 studies in the literature, examined the 50 variables used by researchers to elaborate attitudes towards the education of gifted and stated that none of them had a systematic and substantial predictor of their attitudes towards the education of gifted people [30].

In the qualitative part of the research, it has been tried to determine the opinions of counselors about diagnosis and education of gifted individuals. The majority of counselors have stated that there are problems in both education and diagnosis. Especially, counselors revealed problems related to the reliability of the intelligence test used in diagnosis. In addition, having lack of institutions other than Science and Art Center and problems related to the quality of education are expressed. Also, counselors stated that the diagnosis should be done at an earlier age. Another suggestion from the counselors was separate and free schools with special curriculum for the genius students.

\section{CONCLUSION}

To sum up, when the quantitative and qualitative data brought together, it can be said that counselors working in Turkey are sensitive to education of gifted students. However, some counselors stated that they did not have enough knowledge about gifted education. Further research that focuses on developing the vocational qualifications of counselors in terms of gifted education, can be useful. In that sense, experimental studies can be conducted to improve the positive attitude of the counselors towards the education of gifted students. In addition, studies comparing the attitudes of counselors and teachers from different branches working in Science and Art Center can be conducted. For implementation, in Turkey the diagnosis problems related to the intelligence test are waiting solution. Also, new institutions for gifted students are needed. In that sense, more sophisticated and comprehensive policies in the education of gifted students are needed. In order to increase the positive attitude, prospective counselors should take courses related to education of gifted students in education faculties.

\section{REFERENCES}

[1] Davis, G. A. and Rimm, S. B., Education of the gifted and talented, (5th Ed.). Needham Heights, MA: Allyn \& Bacon, 2004

[2] Ataman, A, “Üstün zekâlı ve üstün yetenekli çocuklar,” Ayşegül Ataman (Ed.), In Özel Eğitime Giriş. Ankara: Gündüz, pp. 173-195, 2005.

[3] Endepohls-Ulpe, M. and Ruf, H, "Primary school teachers' criteria for the identification of gifted pupils," High Ability Studies, vol. 16, no. 2, pp. 219-228, 2005.

[4] Hansen, J. B. and Feldhusen, J. F, "Comparison of trained and untrained teachers of gifted students," Gifted Child Quarterly, vol. 38, no. 3, pp. 115-121, 1994.

[5] Güneş, A, "Investigation of classroom teachers' attitudes and self-efficacy towards gifted education," Journal of Gifted Education and Creativity, vol. 2, no. 1, pp. 12-16, 2015.

[6] Sönmez, D, "Defining the Primary School Teacher Attitudes towards Gifted Students and Their Education (Sample of Silifke District)," Mustafa Kemal University Journal of the Faculty of Education, vol. 1, pp. 65-79, 2017.

[7] Kaya, N. G, "Determination of Attitudes and Opinions of Classroom Teachers about Education of Gifted Students," Education and Science, vol. 44, no. 199, pp. 239-256, 2019.

[8] Tortop, H.S. and Kunt, K, "Investigation of Primary School Teachers' Attitudes towards Gifted Education," International Online Journal of Educational Sciences, vol. 5, no. 2, pp. 441-451, 2013.

[9] Wood, S. M, "Counseling concerns of gifted and talented adolescents: Implications for school counselors," Journal of School Counseling, vol. 7, no. 1, pp. 1-47, 2009.

[10] Wood, S., Portman, T. A. A., Cigrand, D. L., and Colangelo, N, "School counselors' perceptions and experience with acceleration as a program option for gifted and talented students," Gifted Child Quarterly, vol. 54, no. 3, pp. 168-178, 2010.

[11] Mavi, H., "The determination of the opinions and training needs of guidance teachers for superior intellectual students," Unpublished master's thesis, Near East University Graduate School of Educational Sciences, 2017. 
[12] Ersoy, E. and Uysal, R, "Opinions of School Psychological Counselors on Giftedness and Gifted Students' Education,” American Journal of Qualitative Research, vol. 2, no. 2, pp. 120-142, 2018.

[13] Colangelo, N. and Wood, S. M, "Counseling the gifted: Past, present, and future directions," Journal of Counseling \& Development, vol. 93, no. 2, pp. 133-142, 2015.

[14] Carlson, N. N., Holcomb-McCoy, C., and Miller, T. R, "School counselors' knowledge and involvement concerning gifted and talented students," Journal of Counselor Leadership and Advocacy, vol. 4, no. 2, pp. 89-101, 2017.

[15] Ozcan, D. and Uzunboylu, H, "School counsellors' perceptions of working with gifted students," South African Journal of Education, vol. 40, suppl. 1, pp. s1-s9, 2020.

[16] Abu Yazid, A. B, "Counseling and guidance for Malaysian gifted students: a conceptual framework," Journal for the Education of Gifted Young Scientists, vol. 4, no. 1, pp. 21-29, 2016.

[17] Balc1, A, Sosyal Bilimlerde Araştırma, Yöntem, Teknik ve İlkeler. Ankara: Pegem, 2010.

[18] Creswell, J. W. and Plano-Clark, V. L, "The nature of mixed methods research," in Designing and conducting mixed methods research. California: Sage, 2011.

[19] Gagné, F. and Nadeau, L, "Dimensions of attitudes toward giftedness," In A. H. Roldan, (ed.), Gifted and talented children, youth and adults: Their social perspective and culture. NY: Trillium Press, pp. 148-170, 1985.

[20] Tortop, H. S, "Revising of the Validity and Reliability of Turkish Version of the Attitude Scale towards Gifted Education for Teacher," Journal of Gifted Education Research, vol. 2, no. 2, pp. 63-71, 2014.

[21] Yıldırım, A. and Șimșek, H., Sosyal bilimlerde nitel araștırma yöntemleri. Ankara: Seçkin, 2013.

[22] Miles, M, B. and Huberman, A. M., Qualitative data analysis: An expanded sourcebook. Thousand Oaks, CA: Sage, 1994.

[23] Antoun, M., Kronborg, L., and Plunkett, M, "Investigating Lebanese Primary School Teachers' Perceptions of Gifted and Highly Able Students," Gifted and Talented International, 2020. [Online]. Available: https://doi.org/10.1080/15332276.2020.1783398

[24] Peterson, Jean S, "School counselors and gifted kids: Respecting both cognitive and affective," Journal of Counseling \& Development, vol. 93, no. 2, pp. 153-162, 2015.

[25] Kennedy, Kelly; Farley, Jessica, "Counseling gifted students: School-based considerations and strategies," International Electronic Journal of Elementary Education, vol. 10, no. 3, pp. 361-367, 2018.

[26] Cross, Jennifer Riedl; Cross, Tracy L, "Clinical and mental health issues in counseling the gifted individual," Journal of counseling \& development, vol. 93, no. 2, pp. 163-172, 2015.

[27] Maree, J.G, "Gifted education in Africa," In SI Pfeiffer (Ed). APA handbook of giftedness and talent. Washington, DC: American Psychology Association, 2017.

[28] Fisher, E. S., and Kennedy, K. Counseling diverse populations in schools. New York: Oxford University Press, 2016.

[29] Bakar, A. Y. A. and Ishak, N. M, "Counseling services for Malaysian gifted students: An initial study," International Journal for the Advancement of Counseling, vol. 36, no. 4, pp. 372-383, 2014.

[30] Bégin, J. and Gagné, F, "Predictors of attitudes toward gifted education: A review of the literature and blueprints for future research," Journal for the Education of the Gifted, vol. 17, no. 2, pp. 161-179, 1994. 